International Journal of Life Sciences
Available online at http://sciencescholar.us/journal/index.php/ijls
Vol. 3 No. 2, August 2019, pages: $14 \sim 23$
e-ISSN: 2550-6986, p-ISSN: 2550-6994
https://doi.org/10.29332/ijls.v3n2.295

\title{
Impact of Application of Law No 16/2006 About Fisheries and Forestry Agricultural Extension System toward to Performance of Agricultural Extension Workers
}

\author{
(1) corssiant \\ I Putu Addhi Krishnayana a , I Nyoman Suparta ${ }^{\text {b }}$, Ni Wayan Tatik Inggriati c \\ Article history: Received 27 December 2018, Accepted: 30 April 2019, Published: 01 July 2019
}

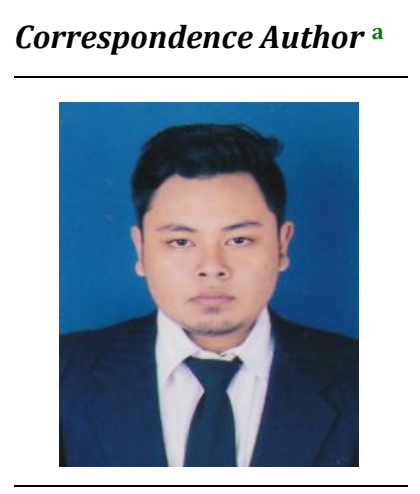

Keywords

agricultural;

extension;

instructor;

motivation;

performace;

\begin{abstract}
This study aims to analyze the relationship of knowledge, attitudes, skills, and characteristics with the motivation and performance of agricultural extension workers after implementing Law No. 16 of 2006. The research location was determined purposively. Sampling uses the stratified quota method. The data collection method is direct and in-depth interviews, observation and documentation. The results of the study showed that the average motivation and performance of agricultural extension workers were in the medium category. Knowledge, attitudes, characteristics, and skills of agricultural extension workers in Tabanan Regency proved to have a significant positive effect on instructor motivation and performance. Knowledge, attitudes, and skills of agricultural extension workers in Gianyar Regency proved to have a real positive effect on motivation and performance. The motivation and performance of extension agents in Gianyar and Tabanan Districts are mostly in the moderate category. The motivation of agricultural instructors in Tabanan has a very significant positive effect on the performance of extension agents, while the motivation of agricultural extension agents in Gianyar Regency has a significantly positive relationship to performance.
\end{abstract}

e-ISSN: 2550-6986, p-ISSN: 2550-6994@ Copyright 2019. The Author. SS Journals Published by Universidad Técnica de Manabí. This is an open-access article under the CC BY-SA 4.0 license (https://creativecommons.org/licenses/by-sa/4.0/) All rights reserved.

\section{Contents}

Abstract 14

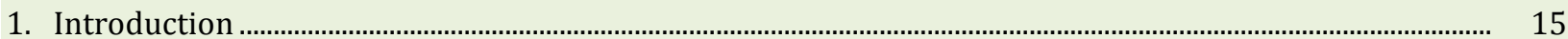

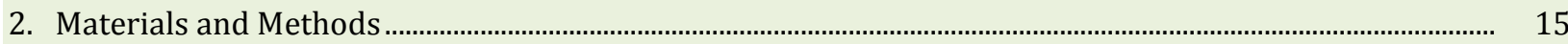

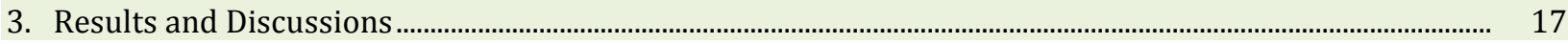

a Udayana University, Denpasar, Indonesia

b Udayana University, Denpasar, Indonesia

c Udayana University, Denpasar, Indonesia 


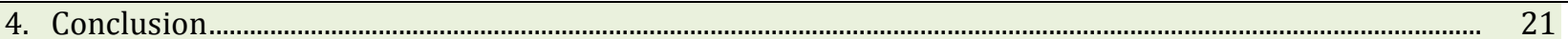

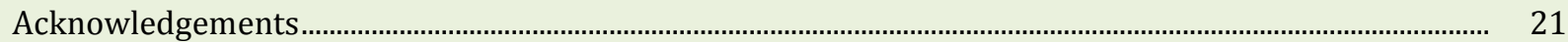

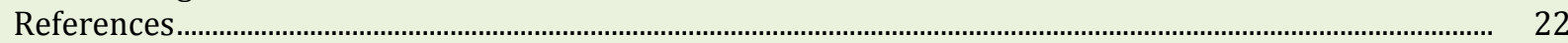

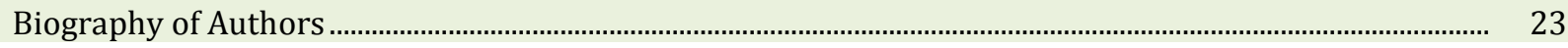

\section{Introduction}

Since Law number 16, the year of 2006 published on the $15^{\text {th }}$ November 2006 (furthermore it called SP3K regulation) where it brings a new extension history in Indonesia. It is much expected by many people who involve in agricultural, fisheries and extension widely.

In the law of the R, I number 16 about the SP3K 2006 is said that agricultural extension system is all development of capability, knowledge, skills, and attitudes of agriculture player through extension. The agricultural extension is a process of study for the players of the agriculture activity with an expectation they want and capable to help and organized their selves to access market information, financial, technology, and other resources as an effort to increase productivity, efficiency, revenue, prosperity and to develop consciousness of environmental functions of live. The implementation of Law regency autonomy after 1999 was unchanged by governments of the province or city. It is clear how important the extension and how it must be implemented within various different attitudes (Puger et al., 2019; Suryani et al., 2018).

Tabanan Regency has selected as the place of the research base on the consideration that Tabanan Regency was the only one regency conducted agricultural extension system base on the SP3K regulation. Even though, its implementation still finds some problems, for examples are extension budget, tools availability, and extension performance. Those are the main problems of the agriculture extension performance.

Apparently, Tabanan Regency is better in case of implementation of the cultural extension (because it really implements the SP3K regulation, professional, more human resources and higher agriculture potential) than Gianyar Regency relatively. Base on the explanation above, writer inspired to do research about motivation and performance of the extension worker after implementation of the SP3K at Gianyar Regency, the center of tourism, while Tabanan Regency has wider agriculture center.

\section{Materials and Methods}

\section{Research Design}

This research was a survey which explained relationship research variables that affect knowledge, skills, motivation, attitude and individual character toward agriculture performance that matching to the SP3K Regulation No. 16/2006. The re-research was conducted by comparison between the Tabanan Regency that already implemented the SP3K Regulation No. 16/2006 and no implemented it yet (Gianyar).

\section{Research Location and Time}

The research was conducted at Gianyar and Tabanan Regencies. Its location was determined with the method of purposive sampling based on certain consideration (Hadi, 1998) as follows:

1) Tabanan Regency already implemented the SP3K No. 16/2006 relatively on extension program as a guideline of extension implementation.

2) Gianyar Regency actually is ready to implement the SP3K No.16/2006 but, up to now it's not yet realized due to some problems of budget so that it can be categorized that Gianyar Regency was not implemented it accordingly.

3) The comparison above was conducted to see the regency that already implemented the SP3K No.16/2006 (Tabanan) and other (Gianyar) who no implemented it yet. Both locations were selected due to the places close to each other and easy to do observation. The locations were assumed as the representative over all of Bali where Tabanan in the west and Gianyar in the east.

Krishnayana, I. P. A., Suparta, I. N., \& Inggriati, N. W. T. (2019). Impact of application of law no 16/2006 about fisheries and forestry agricultural extension system toward to performance of agricultural extension workers. International Journal of Life Sciences, 3(2), 14-23. https://doi.org/10.29332/ijls.v3n2.295 
Research Sample

Respondent for agriculture extension worker was determined with quota sampling technics at both regencies. The stratified quota was held where the same respondents were taken from each stratum and regency.

Some samples were determined quota due to the high homogeneity of the population (Table 1.1). Besides that, Sugiono (2012); Lein \& Setiawina, 2018, said that some samples of explanatory or social research are determined at least $10 \%$ of its population. In this case, the determination of respondent of each government of Tabanan and Gianyar was 35 person but, they were only 21 from the private sector of each regency. So, total respondents observed were 112 people.

Table 1

Population sample determination

\begin{tabular}{llllll}
\hline \multirow{2}{*}{ No } & \multirow{2}{*}{ Agriculture worker } & \multicolumn{2}{c}{ Population (person) } & \multicolumn{2}{c}{ Sample (person) } \\
& & Tabanan & Gianyar & Tabanan & Gianyar \\
\hline 1 & Government sector & 146 & 69 & 35 & 35 \\
2 & Private sector & 32 & 21 & 21 & 21 \\
Sum & 178 & 90 & 56 & 56 \\
\hline
\end{tabular}

Source: Agriculture and Food Vegetations Department of Bali (2016)

\section{Type, Souce and Data Collection}

Primary data is data that direct collect from the respondent, while more second is collected from notes or deportations of the Department of Agriculture and Food Vegetations of Bali Province (2016) or other resources which are trusted. Extension workers as the respondent of the research were the primary data. It consists of quantitative and qualitative where the qualitative data are not numerical but, it numerically with scoring technics. The secondary data of the research was obtained from the linked department i.e. the Department of Agriculture and Food Vegetation, Statistic Center Department of Bali Province, and other supporters which link to the research.

\section{Variable Measurement}

Knowledge variable (X1), attitude (X2), skills (X3), individual character (X4), motivation (Y1) and performance (Y2) were tabulated and measured of all indicators of the research variable with five scales $(1,2$, 3,4 and 5). Variables scored were classified into five categories i.e. very high, high, medium, low and very low or very good, good, medium, bad, very bad. For positive statement, very high response and very good were scored 5 , while very bad and very low responses were scored 1 . On the other way around, for the negative statement that very low and bad response were scored 5 but, for very high and very good responses were scored 1 (Singarimbun \& Effendi, 2006).

\section{Data Analysis}

Accumulated data were tabulated base on each category and analyzed statistically. Analysis techniques used in the research was Structural Equation Modeling (SEM) base on variance or component base the SEM called Partial Least Square (PLS) visual version 1.04bl. stated that the PLS is powerful analysis method because it is not based on how many assumptions they are and have no multivariate normal distribution (indicator with the scale of category, ordinate, interval up to ratio can be used on the same model), and need no much sample. The PLS can analyze and construct which were formed by reflective and formative indicators. 


\section{Results and Discussions}

\section{Descriptive evaluation}

The research results showed that the average score of knowledge respondent overall agricultural extension was 3.62. There was $48.21 \%$ of Tabanan extension workers had high knowledge that links to the working program and the research method self, while at Gianyar Regency most of them (41.07\%) were at medium category. Knowledge of extension workers at Tabanan was higher statistically than at Gianyar but, on average their knowledge was in high category (3.62).

Table 2

Respondent distribution base on the research variable

\begin{tabular}{|c|c|c|c|c|c|c|}
\hline \multirow[b]{2}{*}{ Variable } & \multirow[b]{2}{*}{$\begin{array}{l}\text { Scor on } \\
\text { average }\end{array}$} & \multirow[b]{2}{*}{$\begin{array}{l}\text { Variable } \\
\text { category }\end{array}$} & \multicolumn{2}{|c|}{ Tabanan extension worker } & \multicolumn{2}{|c|}{ Gianyar extension worker } \\
\hline & & & $\begin{array}{l}\text { Sum } \\
\text { (person) }\end{array}$ & Percentage (\%) & $\begin{array}{l}\text { Sum } \\
\text { (person) }\end{array}$ & $\begin{array}{l}\text { Percentage } \\
\text { (person) }\end{array}$ \\
\hline Knowlwdge & 3,62 & High & 27 & 48.21 & 23 & 41.07 \\
\hline Attitude & 3,60 & High & 25 & 44.64 & 26 & 46.43 \\
\hline Skill & 3,80 & High & 22 & 39.29 & 24 & 42.86 \\
\hline Motivation & 3,30 & Medium & 30 & 53.57 & 32 & 57.14 \\
\hline Performance & 3,20 & Medium & 25 & 44.64 & 28 & 50.00 \\
\hline
\end{tabular}

Information:

* Score

1.0-1.8 : Very low/very bad

$>1.8-2.6$ : Low/Bad

$>2.6-3.4$ : Medium

$>3.4-4.2$ : Good

$>4.2-5.0$ : Very high/Very good

**Respondent percentage (Total of respondents $=112$ person)

Average score respondent attitude was 3.60 or positive attitude category. There were $44.64 \%$ of Tabanan and $46.43 \%$ of Gianyar respondents had that category. This was due to the respondent's attitude which already trusted in services given to farmers that collaborated with their orientation and enthusiasm in giving solution on problems they faced.

The research results score on average for the motivation of respondent was 3.30 (medium category). Most of the respondents (53.57 \% from Tabanan and $57.14 \%$ from Gianyar) had high enough motivation. Most of them also motivated by their need and expectation in extension service. High motivation of them due to spirit to reach what they need by doing what they do now. According to Hasibuan (1995), motivation is a movement power which creates passionate work to stimulate people to want to work together, effective and integrated with all effort to reach an ambition.

A respondent from Tabanan had high skills (42.86 \%) but, Gianyar only $30.26 \%$. Most of the respondents (39.29\%) from Gianyar had good enough skills in service as extension workers. From prior knowledge variable point of view, respondent knowledge of Tabanan Regency was also higher than that of Gianyar.

Average score knowledge of Tabanan Regency was 3.20 and most of the respondents $44.64 \%$ (Tabanan Regency) and 50.00 \% (Kabupaten Gianyar) implemented a work program good enough and resulted in output clearly. This showed that agriculture extension workers base on the personal character which needs to be increased to produce better extension workers. Performance of extension workers with very good interaction between extension worker and farmers are diligent, discipline, hard work, creative, high extension frequency, good extension materials, and good extension program. Medium performance category is responsible, innovation and model.

Most of the extension workers (53.57\%) on the age between $35-50$ years old and no older than 65 years old. In general, the research results showed that the extension workers were 47.50 years old and this showed their age on productive category. Sample formal education level of the extension workers was $100 \%$ scholar

Krishnayana, I. P. A., Suparta, I. N., \& Inggriati, N. W. T. (2019). Impact of application of law no 16/2006 about fisheries and forestry agricultural extension system toward to performance of agricultural extension workers. International Journal of Life Sciences, 3(2), 14-23. https://doi.org/10.29332/ijls.v3n2.295 
people (Strata 1) and they follow training more than 3 times. The training is needed to increase technical and non technical services and management. Their work was good enough due to their time service was long enough (6.2 years on average).

\section{Evaluation of Measurement Model}

The measurement model was evaluated with convergent validity, discrimination and association reality of each indicator and variable. Evaluation results of convergent validity and all indicators are valid if its value is higher than 0.50 with t calculate is higher than 1.96 (Table 3 ).

Table 3

Loading factor of indicator of the research variable

\begin{tabular}{|c|c|c|c|c|}
\hline No & Variable & Indicator/Item & Value & t- calculate \\
\hline \multirow[t]{4}{*}{1} & Knowledge & Know about extension basic principle & 0,753 & 16,452 \\
\hline & $(\mathrm{X} 1)$ & To know extension method & 0,807 & 26,249 \\
\hline & & Know extension design & 0,787 & 21,262 \\
\hline & & Know the implementation of extension & 0,830 & 24,524 \\
\hline \multirow[t]{4}{*}{2} & Attitude & Attitude on going extension & 0,871 & 38,597 \\
\hline & $(\mathrm{X} 2)$ & Attitude in understanding extension method & 0,901 & 57,679 \\
\hline & & Attitude about extension design & 0,829 & 20,971 \\
\hline & & Attitude on extension aplication & 0,787 & 21,262 \\
\hline \multirow[t]{3}{*}{3} & Skills & Extension capability & 0,828 & 24,261 \\
\hline & (X3) & Extension method skills & 0,804 & 25,781 \\
\hline & & Extension design skills & 0,841 & 28,123 \\
\hline \multirow[t]{4}{*}{4} & Characteristic & Age & 0,862 & 26,557 \\
\hline & $(\mathrm{X} 4)$ & Education & 0,889 & 34,459 \\
\hline & & Training & 0,706 & 9,225 \\
\hline & & Time service & 0,881 & 21,461 \\
\hline \multirow[t]{3}{*}{5} & Motivasi & Needs & 0,862 & 26,557 \\
\hline & (Y1) & Expextation & 0,889 & 34,459 \\
\hline & & Push & 0,706 & 9,225 \\
\hline \multirow[t]{9}{*}{6} & Work (Y2) & Deligent & 0,831 & 15,385 \\
\hline & & Discipline & 0,881 & 21,461 \\
\hline & & Incharge & 0,725 & 36,597 \\
\hline & & Innovation & 0,888 & 52,679 \\
\hline & & Creative & 0,823 & 24,971 \\
\hline & & Model & 0,710 & 55,262 \\
\hline & & Extension working plan & 0,693 & 21,261 \\
\hline & & Mecanism and working method & 0,721 & 24,781 \\
\hline & & Extension material & 0,921 & 27,123 \\
\hline
\end{tabular}

The research variable AVE value was above 0.50. It means all variability which happened on the research indicators could be explained more than $50 \%$ with latent on reliability because of measurement mistake (Table 4).

Table 4

AVE value and its comparison with variable correlation

\begin{tabular}{cll}
\hline No & Research Variable & AVE Value \\
\hline 1 & Knowledge (X1) & 0,732 \\
2 & Attitude (X2) & 0,652 \\
3 & Skills (X3) & 0,538 \\
\hline
\end{tabular}




\begin{tabular}{lll}
\hline 4 & Characteristic (X4) & 0,780 \\
5 & Motivation (Y1) & 0,553 \\
6 & Performance of extension worker & 0,751 \\
\hline
\end{tabular}

Square root value of average variance extracted latent variable is bigger than another latent variable correlation coefficient. This indicates that six latent variables have good discrimination validity.

Table 5

Reliability composite value and latent variable crombach's alfa

\begin{tabular}{clll}
\hline No & Latent variable & Composite Reliability & Cronbach's Alpha \\
\hline 1 & Knowledge & 0,773 & 0,705 \\
2 & Attitude (X2) & 0,801 & 0,736 \\
3 & Skills (X3) & 0,852 & 0,863 \\
4 & Characteristic (X4) & 0,841 & 0,636 \\
5 & Motivation (Y1) & 0,799 & 0,747 \\
6 & Performance (Y2) & 0,859 & 0,924 \\
\hline
\end{tabular}

The research results in Table 5 showed that all indicator block were capable to measure the research variable. All indicators are consistent in the measurement of attitude, motivation, perception, social interaction, decision, and success of effort over $70 \%$.

\section{Structural Model Evaluation}

The structural model was evaluated with pay attention on $\mathrm{Q}^{2}$ predictive relevance model that measures how good observation value was resulted by the $Q^{2}$ model base on determination coefficient of all $Q^{2}$ dependent variable which had value for $0<Q^{2}<1$, the closer the value 1 , the better structural model of the research. To know more complete. About evaluation results of the goodness of fit model it can be seen in Table 6 as follows:

Table 6

Composite reliability value and latent variable Cronbach's alfa

\begin{tabular}{|c|c|c|c|}
\hline No & Latent variable & $\mathrm{R}^{2}$ & $\mathrm{Q}^{2}$ \\
\hline 1 & Motivation (Y1) & 0,754 & \multirow{2}{*}{0,786} \\
\hline 2 & Performance of extension worker (Y2) & 0,690 & \\
\hline
\end{tabular}

Information: $\mathrm{Q}^{2}=1-\left(1-\mathrm{R}_{1}{ }^{2}\right)\left(1-\mathrm{R}_{2}^{2}\right)=0,786$

\section{Hypothesis Test}

Hypothesis test was conducted with bootstrapping to see $t$ - calculated value and tract coefficient value on each tract that affects directly partially. Hypothesis test was conducted with t-test on each direct effect tract partially. Test results of tract coefficient validation on each track of direct effect can be seen in Table 7 .

Table 7

Evaluation result of tract coefficient validation partialy (t-test)

\begin{tabular}{lllll}
\hline \multirow{2}{*}{ Correlation among variable } & \multicolumn{2}{c}{ Tabanan Regency } & \multicolumn{2}{c}{ Gianyar Regency } \\
\cline { 2 - 5 } & $\begin{array}{l}\text { Tract } \\
\text { coefficient }\end{array}$ & $\begin{array}{l}\text { T- } \\
\text { Statistics }\end{array}$ & $\begin{array}{l}\text { Tract } \\
\text { coefficient }\end{array}$ & T-Statistics \\
\hline Knowledge $\rightarrow$ Motivation & 0,492 & $3,169 \mathrm{hs}$ & 0,292 & $1,969 \mathrm{~s}$ \\
Attitude $\rightarrow$ Motivation & 0,295 & $2,062^{\mathrm{s}}$ & 0,277 & $1^{-982} \mathrm{~s}$ \\
\hline
\end{tabular}

Krishnayana, I. P. A., Suparta, I. N., \& Inggriati, N. W. T. (2019). Impact of application of law no 16/2006 about fisheries and forestry agricultural extension system toward to performance of agricultural extension workers. International Journal of Life Sciences, 3(2), 14-23. https://doi.org/10.29332/ijls.v3n2.295 


\begin{tabular}{|c|c|c|c|c|}
\hline Skills $\rightarrow$ Motivation & 0,447 & $3,001 \mathrm{hs}$ & 0,307 & $2,101^{s}$ \\
\hline Characteristic $\rightarrow$ Motivation & 0,226 & $2,094 \mathrm{~s}$ & 0,126 & $1,894 \mathrm{~ns}$ \\
\hline Knowledge $\rightarrow$ Performance of extension worker & 0,331 & $2,803^{\mathrm{hs}}$ & 0,239 & $2,103 \mathrm{~s}$ \\
\hline Attitude $\rightarrow$ Performance of extension worker & 0,325 & $3,062 \mathrm{hs}$ & 0,375 & $3,215 \mathrm{hs}$ \\
\hline Skills $\rightarrow$ Performance of extension worker & 0,437 & $3,201 \mathrm{hs}$ & 0,204 & $1,965 \mathrm{~s}$ \\
\hline Characteristic $\rightarrow$ Work of extension worker & 0,026 & $1,194 \mathrm{~ns}$ & 0,016 & $1,049 \mathrm{~ns}$ \\
\hline Motivation $\rightarrow$ Performance of extension worker & 0,373 & $2,900 \mathrm{hs}$ & 0,299 & $1,990^{\mathrm{s}}$ \\
\hline
\end{tabular}

Information: hs = highly significant $(\mathrm{P}<0.01)$

$$
\begin{aligned}
& \mathrm{s}=\operatorname{significant}(\mathrm{P}<0.05) \\
& \mathrm{ns}=\text { non significant }(\mathrm{P}>0.05)
\end{aligned}
$$

From the formula model and results of tract coefficient validation on each track to direct effect in Table 7 above can be determined the results of the hypothesis test as follows. Knowledge of Tabanan respondent (X1) affect positive, highly significant $(\mathrm{P}<0.01)$ on motivation and work of extension workers. This result showed positive tract value $\mathrm{t}$-calculated 3.169 and $2.803(\mathrm{t}$ - calculated $-=2.560)$. But, knowledge level on Gianyar respondent only significant effect $(\mathrm{P}<0,05)$ on motivation and performance of extension workers, so the hypothesis of respondents knowledge affects positive significantly to the motivation and performance of extension worker and it could be accepted.

Tabanan respondent attitude $(\mathrm{X} 2)$ positive significant effect $(\mathrm{P}<0.01)$ on motivation and work of extension worker, but the attitude of Gianyar respondent only affect significant $(\mathrm{P}<0.05)$ on motivation and performance of extension worker. Those were showed by tract coefficient with a positive value, $t-$ calculated $>1.960$, so the hypothesis of respondent attitude affects positive significantly on motivation and work of extension worker could be accepted. Skills of Tabanan Regency respondent (X1) affect highly positive (P < 0.01) on motivation and performance of extension worker. It was shown on tract coefficient that positive value 0.447 and 0.437 with $\mathrm{t}$-calculated 3.001 and 3.201 ( $\mathrm{t}$ - calculated $>2.560$ ), while at Gianyar Regency it skills only significant effect on motivation $(\mathrm{P}<0.05)$, but work of extension worker affect positive highly significant $(\mathrm{P}<0.05)$.

Characteristic of Tabanan respondent (X1) affect positive significant $(\mathrm{P}<0.05)$ toward motivation and no effect $(\mathrm{P}>0.05)$ toward the performance of extension but, at Gianyar Regency, it results showed no significant effect on motivation and performance $(\mathrm{P}>0.05)$. These results were shown by tract coefficient positive value 0.226 with $\mathrm{t}$ - calculated $2.094(\mathrm{t}$ - calculated $>1.960)$, so Tabanan respondent characteristic affect significant positive toward motivation could be accepted, while on it performance could not be proved and hypothesis of Gianyar Regency respondent was rejected.

Tabanan respondent motivation (Y1) proved highly significant positive affect $(\mathrm{P}<0.01)$ toward the work of extension worker and at Gianyar Regency showed significant $(\mathrm{P}<0.05)$. These results were shown on tract coefficient positive value with $\mathrm{t}$ - value $>\mathrm{t}$-table $(\mathrm{t}-$ calculated $>1.960$ and 2.560$)$, so respondent motivation hypothesis significant positive affect toward work of extension worker and could be accepted.

Knowledge had a significant positive correlation with the performance of agriculture extension worker that may cause of many training were followed by agriculture extension workers such as agriculture extension basic training, artificial insemination, meat cattle estate, forage preservation of animal feed and village agribusiness effort. Correlation of significant positive attitude toward motivation and work of extension worker means the hypothesis of the research was accepted. This can be understood that the positive attitude of agriculture extension performance could support the work of them in order to develop agriculture and animal farms. Positive attitude form of agriculture extension worker's at Tabanan and Gianyar Regencies are an honest attitude on service of extension worker and always provide time for farmers to develop agriculture business. High skills of agriculture extension worker were also supported by talented used of extension tools on agribusiness animal farm for example whiteboard, poster and pamphlet.

High motivation of agriculture extension worker's was supported also by an interpersonal good relationship with senior and sesame members. Result of $\mathrm{F}$ test in Table 5.16 showed that knowledge variable, attitude, skills, and individual characteristic affect highly significant $(\mathrm{P}<0.01)$ simultaneously toward motivation and performance of extension worker $(\mathrm{t}-$ calculated $>3.180)$ and determination coefficient value $\left(R^{2}\right) 0.754$ and 0.690 respectively. So that, the result gave information altogether about motivation and 
performance of extension worker were determined by a variable of $75.40 \%$ and $69.60 \%$. The higher the attitude knowledge level, skills, and individual character, the higher of motivation and performance of them.

Table 8

Results of tract coefficient evaluation simultaneously ( $\mathrm{F}$ - test)

\begin{tabular}{cllll}
\hline No & Predictor variable & Creterion variable & $\mathrm{R}^{2}$ & $\mathrm{~F}$ \\
\hline (1) & $\begin{array}{l}\text { Knowledge, Attitude, Skills and } \\
\text { Characteristic }\end{array}$ & Motivation & 0,754 & $74,925^{\text {hs }}$ \\
(2) & $\begin{array}{l}\text { Knowledge, Attitude, } \\
\text { Skills and Characteristic }\end{array}$ & $\begin{array}{l}\text { Performance of } \\
\text { extension worker } \\
\text { (3) }\end{array}$ & 0,690 & $53,456^{\text {hs }}$ \\
& $\begin{array}{l}\text { Knowledge, Attitude, } \\
\text { Skills and Characteristic and }\end{array}$ & $\begin{array}{l}\text { Work extension } \\
\text { worker }\end{array}$ & 0,720 & $45,133^{\text {hs }}$ \\
\hline Information: hs $=$ highly significant & & &
\end{tabular}

\section{Conclusion}

Average motivation and performance of agriculture extension worker was medium category after the SP3K No. 16/2006. was implemented in Bali Province. Knowledge and skills agriculture extension worker at Tabanan Regency affects highly significant toward extension motivation of the extension worker while attitude and characteristic only significant positive affect toward motivation. Knowledge, attitude, skills agriculture extension worker at Tabanan Regency proved positive highly significant effect toward their work but, there was no correlation on the individual characteristic. Knowledge, attitude, and skills of agriculture extension worker at Gianyar proved positive affect toward motivation, while their characteristic no effect toward motivation. Knowledge and skills agriculture extension worker at Gianyar Regency proved positive significant effect toward performance and attitude positive correlated really toward the extension worker. But, there was no correlation individual characteristic toward the performance of the extension worker.

Most of motivation and performance of extension worker of Gianyar and Tabanan Regencies positive highly significant effect toward extension worker. But, agriculture extension worker of Gianyar Regency real positive correlation to word performance.

\section{Suggestions}

For agriculture extension workers are needed to increase their performance particularly in the field of extension and human resources competency through better extension technics i.e. properly application of extension material which is needed, so that knowledge and skills increase gradually.

\section{Acknowledgments}

Firstly, the writer would like thank to agriculture extension workers of Government of Tabanan and Gianyar, Bali Provinces who already gave time for the researchers to talk and collect some data related to this research. Thank also to friends who are not able to call their name one by one that already helps physical and mental for success in the research application.

Krishnayana, I. P. A., Suparta, I. N., \& Inggriati, N. W. T. (2019). Impact of application of law no 16/2006 about fisheries and forestry agricultural extension system toward to performance of agricultural extension workers. International Journal of Life Sciences, 3(2), 14-23. https://doi.org/10.29332/ijls.v3n2.295 


\section{References}

Adjid, D. A. (1994). Posisi Penyuluhan Pertanian Dalam Dinamika Respon Usahatani terhadap Tantangan Kemajuan. Departemen Pertanian, Jakarta.

Ahmadi, A. (1991). Psikologi sosial, cet I. Jakarta: Rineka cipta.

Allport, G. W., Clark, K., \& Pettigrew, T. (1954). The nature of prejudice.

Anwar, M. M., \& Meki, A. R. M. (2003). Oxidative stress in streptozotocin-induced diabetic rats: effects of garlic oil and melatonin. Comparative Biochemistry and Physiology Part A: Molecular \& Integrative Physiology, 135(4), 539-547. https://doi.org/10.1016/S1095-6433(03)00114-4

Armstrong, M., \& Baron, A. (1998). Performance management: The new realities. State Mutual Book \& Periodical Service.

Arnold, H. J., Feldman, D. C., \& Hunt, G. (1992). Organizational behaviour: a Canadian perspective. McGraw-Hill Ryerson.

Bahua, M. I., Jahi, A., Asngari, P. S., Saleh, A., \& Purnaba, I. G. P. (2010). Faktor-faktor yang mempengaruhi kinerja penyuluh pertanian dan dampaknya pada perilaku petani jagung di Provinsi Gorontalo. Jurnal Ilmiah Agropolitan, 3(1), 293-303.

Berlo, D. K. (1977). Communication as process: Review and commentary. Annals of the International Communication Association, 1(1), 11-27. https://doi.org/10.1080/23808985.1977.11923667

Campbell, J. Y., \& Shiller, R. J. (2001). Valuation ratios and the long-run stock market outlook: An update (No. w8221). National bureau of economic research.

Dajan, A. (1986). Pengantar metode statistik jilid I. Jakarta: LP3ES.

Darmawan, M. S. (2010). Pitting corrosion model for reinforced concrete structures in a chloride environment. Magazine of Concrete Research, 62(2), 91.

Hadi, M. N., \& Arfiadi, Y. (1998). Optimum design of absorber for MDOF structures. Journal of Structural Engineering, 124(11), 1272-1280.

Hamzah, B. U. (2008). Teori motivasi dan pengukurannya. Jakarta: Bumi Aksara.

Hasibuan, M. S. (2005). Manajemen sumber daya manusia edisi revisi. Jakarta: Bumi Aksara.

Hasibuan, Z. A. (2000). Multi-dimension Concept-based Information Retrieval System. In Proceedings of ALL/ACH 2000 Conference, Glasgow, UK.

Indonesia, U. U. R. (2014). Nomor 16 tahun 2006 tentang sistem penyuluhan pertanian, perikanan, dan kehutanan.

Lein, A. A., \& Setiawina, N. D. (2018). Factors affecting the fishermen household income and welfare. International Research Journal of Management, IT and Social Sciences, 5(4), 80-90. https://doi.org/10.21744/irjmis.v5n4.266

Makmun, A. S. (1996). Analisis Posisi Pendidikan. Jakarta: Biro Perencanaan Depdikbud.

Mangkunegara, A. A. P. (2000). Manajemen sumber daya manusia perusahaan. Remaja Rosdakarya.

Pertanian, D. (2009). Dasar-Dasar Penyuluhan Pertanian. Deptan. Jakarta.

Puger, A., Puspani, E., Nuriyasa, I., \& Yupardhi, W. S. (2019). Effects of replacement of fish mill with golden snail mill in ration to performance of male Bali duck. International Journal of Life Sciences, 3(1), 25-30. https://doi.org/10.29332/ijls.v3n1.243

Singarimbun, M. Effendi. 2006. Metode Penelitian Survai.

Singarimbun, M., \& Effendi, S. (1989). Metode dan Proses Penelitian. Metode Penelitian Survai. Jakarta (ID): Lembaga Penelitian, Pendidikan, dan Penerangan Ekonomi dan Sosial (LP3ES).

Sugiono, A. (2009). Manajemen Keuangan untuk Praktisi Keuangan. Jakarta: Grasindo.

Sulistiyani, A. T. (2006). Rosidah, 2003, Manajemen Sumber Daya Manusia: Konsep, Teori dan Pengembangan Dalam Konteks Organisasi Publik. Jakarta: Graha Ilmu. Suliyanto.

Suryani, S. A. M. P., Arya, I. W., \& Suparta, I. M. (2018). Pollution with saprobic index and nutrition value coefficient of fish. International Journal of Life Sciences, 2(2), 30-41. https://doi.org/10.29332/ijls.v2n2.134

Yusuf, S. R., Ahmed, B. I., Chaudhary, J. P., \& Yusuf, A. U. (1998). Laboratory evaluation of some plant products for the control of maize weevil (Sitophilus zeamais motsch.) in stored maize. ESN Occassional publications, 31, 203-213. 


\section{Biography of Authors}

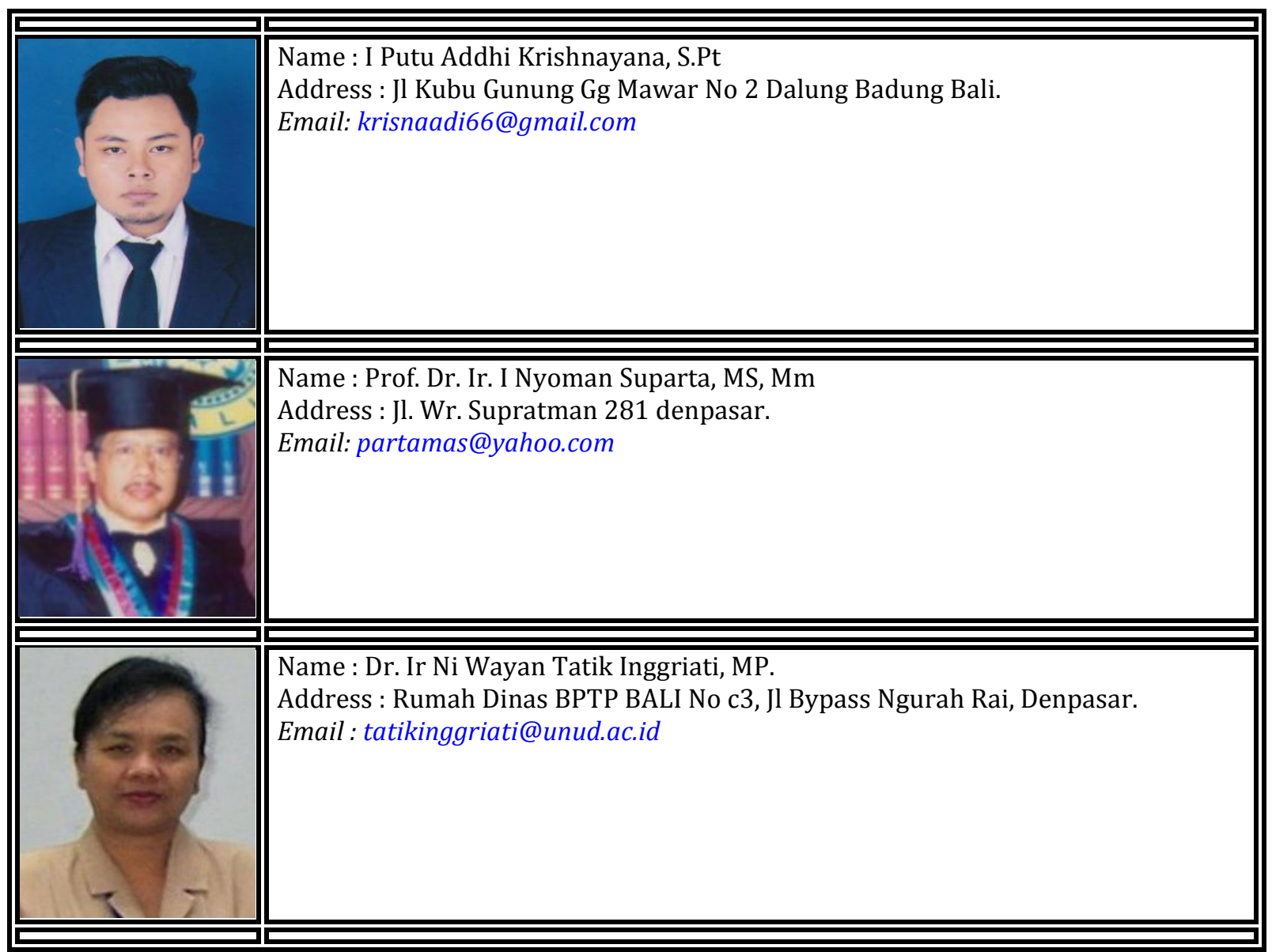

Krishnayana, I. P. A., Suparta, I. N., \& Inggriati, N. W. T. (2019). Impact of application of law no 16/2006 about fisheries and forestry agricultural extension system toward to performance of agricultural extension workers. International Journal of Life Sciences, 3(2), 14-23. https://doi.org/10.29332/ijls.v3n2.295 